\title{
Research on the reform of computer science and technology specialty in the context of industry university cooperation
}

\author{
Xiang-cai ZHU \\ School of Information Science and Technology \\ Taishan University \\ Tai' an City, Shandong Province, China \\ zhuxiangcai@126.com
}

\author{
De-yun YANG \\ School of Information Science and Technology \\ Taishan University \\ Tai' an City, Shandong Province, China \\ yangdeyundisk@163.com
}

\begin{abstract}
In the integration and development of the depth of school enterprise under the background of the computer science and technology professional advantages and characteristics, adhere to the application goals, professional construction, reflected in the curriculum system, teaching system, teaching system and management system and other aspects of the active exploration, bold innovation, form the characteristic of professional. And we establish the complete teaching system, teaching system, curriculum system, teaching evaluation system, using the "5M5W Teaching Model", so as to improve the students' practical skills, improve the teachers' ability of scientific research, improve the school level.
\end{abstract}

Keywords—School Enterprise Depth Integration; Curriculum System; Teaching Model

\section{INTRODUCTION}

Department of computer science and technology is a provincial "11th Five-Year", "12th Five-Year" key disciplines in the professional and professional brand, computer application technology, software engineering and other related professional computer formed a professional group, relying on discipline advantages, based on the local regional economy, for the computer industry to carry out the direction of research and service, pay attention to the integration of production and education to achieve, "school enterprise win-win, cooperative education" objective.

In the background of the State advocates go deep cooperation development, we cooperate with the surrounding enterprises, combined with regional advantages and industrial characteristics of specialty construction, training high-level application-oriented personnel in Tai'an city of electronic information, computer software industry etc.. We should give full play to the advantages of disciplines and specialties and provide information services, product design and technical training for local construction.

Study on the reform of professional computer science and technology under the background of cooperation, mainly through the integration of production and education, explore a construction of a high level of "academic + project" teachers, training applied talents of cooperative road, in order to improve the students' practical skills, improve the teachers' scientific research ability to improve the school level.

\section{ADVANTAGES AND FEATURES}

The school has excellent geographical location, convenient transportation, the economic circle around Ji'nan, the mountain, the water, the saint tourist resource center. The inheritance of school history, relying on regional advantages, in the service of local characteristics, development school of thought, gradually formed the following theory: (1) the role of traditional educational advantages, cultivating applied talents, (2) the use of cultural resources of celebrities with mountains, cultivating applied talents with the Mount Tai cultural heritage, and (3) to serve the local culture talents to meet the needs of economic development. Give full play to the advantages of disciplines and specialties and provide technical support and services for local construction.

Give full play to the advantages, the formation of the following characteristics: (1) the formation of the internal quality assurance system of applied talents training and training scheme "upgrade version of the application type" university talents, and gradually build up the characteristics of the teaching quality supervision and guarantee system, (2) cooperative education way, and (3) College of science and technology innovation growing ability, outstanding achievements in national academic competitions in the "Challenge Cup" competition, science and technology innovation and entrepreneurship competition and other high level 
students, the professional group was named Shandong province school enterprise cooperation in personnel training of advanced units, advanced collective school science and technology innovation.

By strengthening the integration of production and education, providing a rare opportunity for the construction of cultivating high-quality talents and upgrade the school computer application "of the University, the school characteristics and advantages will be brought into full play, so as to promote local economic development, promote the school, academic and professional development to upgrade.

\section{GOALS AND PRINCIPLES}

Around "this is the goal of application-oriented university building upgrades, resource integration, cohesion, deepening the comprehensive reform of education and teaching, optimize the curriculum system, highlighting the characteristics, build a distinctive high level upgrade application oriented university.

Cooperation with enterprises, in the advantage of resources at the same time, make full use of the teaching resources of the school, and cyber source site and library resources, professional development and characteristics to explore the road of integration, through the application of the teaching environment to create first-class talents, cultivate enterprise and satisfy the requirement of the local economic development professionals.

Adhere to moral education first principle, adhere to the practice of thinking innovation, quality improvement, enhance the comprehensive ability principle, adhere to the combination of theory and practice, inside and outside the class, the realization of three-dimensional teaching principles; adhere to the training of students' individual development and characteristics of the principle, adhere to the service and to enterprise demand driven principle.

\section{RESEARCH CONTENTS}

In the course of co construction, we should explore the ways of school enterprise cooperation, the teaching staff and curriculum system, the teaching system and resource construction and management system, and make bold innovations to form distinctive features of the profession.

\section{A. Strengthen the construction of teaching staff}

The construction of teaching staff is the key to co construction. Through professional construction, it will provide a good atmosphere and space for the training of professional teachers' scientific research ability and integrate teaching research and scientific research. Take social demand as the driving force, carry on the application development research, realize the high integration of scientific research and application innovative talents training. We should adjust the discipline team and the direction of teaching and research, encourage teachers to develop research and learning in enterprises, employ technical personnel from enterprises to communicate in schools, and improve their professional quality. We should foster innovation ability and encourage teaching innovation, scientific research innovation and application of technology. We should build a contingent of teaching and scientific research teachers with high level of business, strong teaching and scientific research ability and rich practical experience.

\section{B. Explore the all-round and three-dimensional mode of talent training}

The training of talents should be based on the requirements of enterprises for talent specifications, and constantly improve and optimize the personnel training system, including quality monitoring system, operation guarantee system and organizational management system. School enterprise joint training talents is the inevitable way, only cooperation to jointly build the personnel training system, to achieve a combination of research, the unity of theory and practice, in order to break through the traditional education single knowledge mainly in the classroom teaching, enhance the construction of theory teaching, practice teaching and the comprehensive quality of the effective combination of teaching system. Adopt "open" measures and work closely with enterprises, governments and scientific research institutes. According to the different requirements of the society for professionals, we should adopt a "pluralistic" way of training, and explore a comprehensive and three-dimensional mode of personnel training.

\section{Building a dynamic, multi platform and multi module curriculum system}

Combined with the technical requirements of enterprises, we should build the curriculum system, optimize the curriculum content, and highlight the curriculum features. According to the students' common development and professional characteristics requirements of constructing the basis of constructing curriculum module course platform, dynamic development of students' personality and social needs of the enterprise, with a general platform to ensure the basic quality and development potential of the students, to students' professional knowledge professional platform to ensure system integrity, to ensure students' engineering quality outstanding quality platform. The dynamic module course in the platform should be graded to ensure the development of students' personality, professional specialty and social adaptability. 


\section{Building a diversified and three-dimensional specialized teaching system}

The knowledge and technology involved in school enterprise cooperation have the characteristics of extensive application, high technology, strong engineering and leading edge. Therefore, we should pay special attention to the cultivation of students' practical ability, professional quality and innovative spirit. Adhere to the ability training as the main line, closely around the "development of learning ability, practical ability, innovation ability, team cooperation ability and professional teaching system, from" to meet the needs of the society and adapt to the occupation, to adapt to the development of self "point of view, it is necessary to develop the post ability, but also cultivate the ability not only to cultivate professional industry; ability, but also cultivate comprehensive ability; it is necessary to develop employment ability, but also cultivate entrepreneurial ability. Professional construction will give full play to the enterprise's practice curriculum support, especially enterprise training, in the theoretical knowledge, practical ability and professional accomplishment and so on, the students' all-round, three-dimensional quality training.

Adopt flexible and diverse teaching model, carry out teaching in many directions and in many ways. To study theoretical knowledge, we should use classroom teaching, network teaching, curriculum report writing and other means. To practice teaching, we use curriculum experiment, graduation design, science and technology innovation, enterprise project experience and fund project participation.

\section{E. Build a platform for sharing resources}

By means of school enterprise cooperation, we can make use of enterprise resources, teachers and practical training bases to realize the sharing of resources among talents, equipment and information". And enterprises to build a teaching practice base and employment base, sharing of information talent needs of the enterprise, carry out targeted orientation training; sharing project development experience, optimize the curriculum system and content sharing; personnel and laboratory equipment, improve the competitiveness of enterprises and the students' practice ability; the development of project management, project cooperation. We shall establish a platform for the development of both engineering ability and comprehensive quality of mutual support, organic cohesion and gradient development.

\section{CONCRETE METHODS AND MEASURES}

Establish a complete professional teaching system, teaching materials system, curriculum system, teaching evaluation system and so on, and adopt the new "5M5W practice teaching model" to improve students' practical ability.

\section{A. Teaching System}

The construction of teaching system: improve the professional teachers' skills and abilities; broaden the sources of teachers, strengthening the introduction of good business management, business talents, optimize the structure of teachers; encourage existing teachers, improve teachers' theoretical level and practical experience; actively carry out research activities, and constantly improve the teaching ability of teachers regularly; the training of professional teachers, send some teachers to corporate learning, enhance their industry practice ability; build a high level of teachers.

\section{B. Construction of the teaching material system}

We select the excellent teaching materials, classroom teaching and practice teaching to adapt to the needs of the construction characteristics; course group; encourage the development of multimedia courseware for teachers, complete the exercises and case materials preparation.

\section{Construction of curriculum system}

Through the establishment of curriculum system construction of professional courses; teaching methods and means of innovation, promote independent learning; in the teaching mode, the teaching method of "5M5W teaching mode" of this kind of combat style, implement mode, and classroom training combined focus on practice, in practice experience in theory, the theory of experience fusion learning; gradually improve teaching conditions, reference room of a certain size built has close relationship with the professional,; establish professional network teaching platform, expansion of resources, to carry out online Q \& A, of course learning and communication needs of students, and play its special function to encourage the teaching; professional students to participate in the design competition, entrepreneurship competition to guide students to the market, to the enterprise and society.

\section{Construction of teaching evaluation system}

- Strengthen formative assessment; implement monitoring of students' learning process, and record teachers' evaluation of students' learning process. Perfect summative evaluation and realize diversity of assessment means. The examination uses the written examination, the report, the curriculum paper, the curriculum design and so on each kind of form evaluation way. Continue to implement and improve the supervision system, strengthen the quality of teaching and teaching of teachers monitoring. 
- Maintain the existing professional practice base, production and research base and graduate employment base, to provide students with the guarantee of internship, so that the professional practice teaching plays the role of demonstration radiation.

- Enrich the professional library resources allocation; the establishment of campus network learning platform, to create a good learning atmosphere and environment, to meet the needs of students training, extracurricular training, communication and interaction between teachers and students, the construction of training base outside contact.

\section{E. Construction of the platform of cooperation and communication}

Based on the existing international exchanges and cooperation, and strive to broaden the channels, strengthen cooperation with domestic and foreign well-known universities, educational institutions and international well-known enterprises, build exhibition and exchange platform, to enhance the international influence of the professional; the conditions allow, hire more high level at home and abroad teachers, send more teachers visiting the study; construction of students' sustainable development of the overpass, realize the goal of diversification; strengthen the construction of enterprise, relying on, through professional seminars, carry out business activities such as holiday visits and other professional knowledge, let students understand the demand of talents, make more outstanding students to learn the specialty knowledge and skills, to better meet the needs of local enterprises.

Clear the responsibility, assume the responsibility, and form a "resource sharing + responsibility sharing" effective mechanism. Implementing the quantitative performance evaluation system of laboratory utilization, the school enterprise unified evaluation system for full-time teachers, and the quality responsibility system for students' training courses.

\section{F. 5M5W practice teaching mode}

We adapt the new 5M5W practice teaching mode to improve students' practical ability. In undergraduate students, $5 \mathrm{M}$ teaching model was attempted and divided into five different modules by computer level test (M1-M5). M1 according to the students' computer level weak, M2 for the general level of computer students in middle level students M3 computer, M4 computer for good level of students, for students with a high level of computer M5. Mode classification is shown in Table 1.

TABLE I. 5M GRADING TABLE

\begin{tabular}{cccccc}
\hline grading & Third term & fourth term & fifth term & sixth term & seventh term \\
\hline M1 & two & two & two & two & two \\
M2 & four & four & four & four & Integrated design \\
M3 & six & six & six & six & Integrated design \\
M4 & eight & eight & eight & eight & Integrated design \\
M5 & ten & ten & ten & Integrated design & $/$ \\
\hline
\end{tabular}

The 5M teaching model is based on the basic teaching model, and the training of the students' practical ability needs to follow the "5W teaching mode" (practice teaching mode). Meaning of "5W" teaching mode is defined as "Who, What, Why, When, Which" five parts, namely let students make clear in the practice of who to do, what to do (Who) (What) (Why), why to do, when to do, (When) how do (Which). The teacher in the student's strengths and interests groups, test assumes that the title "game development", some students also love to participate in good art imagination, scene design, research and development capability of the active application software development, some students usually like playing games, driving forward the demo of the game, but the general ability of research and development. Work carefully, for code testing, some lack of interest in research and development, but the marketing experience, can participate in market research. The classification of practice is shown in Table 2.

TABLE II. 5W GRADING TABLE

\begin{tabular}{|c|c|c|c|c|c|}
\hline grading & first & second & third & fourth & fifth \\
\hline W1 & Imaginative & $\begin{array}{l}\text { Strong R \& D } \\
\text { capability }\end{array}$ & Flexible operator & Conscientious person & An economic thinker \\
\hline W2 & Scene design & Game development & Game testing & Code testing & Market Research \\
\hline W3 & Simulated feeling, & Ability training & BUG search & System optimization & Business Analytics \\
\hline W4 & $\begin{array}{l}\text { Prophase of research } \\
\text { and development }\end{array}$ & $\mathrm{R} \& \mathrm{D}$ period & $\begin{array}{l}\text { Debugging } \\
\text { period }\end{array}$ & Finishing period & Application phase \\
\hline W5 & Graphics processing & $\mathrm{R} \& \mathrm{D}$ tools & $\begin{array}{l}\text { Manual } \\
\text { operation }\end{array}$ & Testing tools & Economics research \\
\hline
\end{tabular}


"5W" teaching mode is a kind of students and analysis of practical problems, a new teaching method to cultivate students practical ability and potential development, progress is a kind of teaching method, students to create a learning, training, research, questioning and feedback process, so as to improve the ability of discovering and solving problems the.

The advantages of this teaching mode is helpful to arouse the curiosity of the students, arouse their consciousness and initiative of students, so as to improve the students' ability to analyze and solve problems, so as to timely and effectively promote the transformation from theory to practice, to truly achieve the combination of theory and practice, and help to strengthen students' practice practical ability.

This new teaching mode can not only change the students and change teachers as follows: Students' learning process change, learning is not only a process of knowledge and memory, is the process of information processing, students through active information acquisition, information processing, information dissemination, access to knowledge, to improve ability; change of students' role, is no longer the passive receivers of knowledge acquisition, processing, active and information; to change the role of teachers, knowledge is no longer a ruler, but guidance, service.

\section{SUMMARY}

This paper studies the integration and development in the depth of school enterprise under the background of "service in place, special development school of thought, the use of computer science and technology professional advantages and characteristics, adhere to the application goal, through strengthening the integration of production and education, grasp the opportunity for the construction of high-quality talent and upgrade the school computer application" university. Professional construction, reflecting the curriculum system, teaching system, teaching materials system and management system, and other aspects of active exploration, bold innovation, the formation of professional distinctive features. And we establish of a complete teaching system, teaching system, curriculum system, teaching evaluation system, using the "5M5W teaching mode", so as to improve the students' practical skills, improve the teachers' ability of scientific research, improve the school level.

\section{ACKNOWLEDGMENT}

This research has been partially supported by project (No.201601026035) of the Comprehensive Reform of Production and Study Cooperation in Higher Education Division of the Ministry of Education; the project of scientific research development of universities in Shandong (No.: J14LN68); the science and technology development project of Tai'an city (No.: 20140630- 6); the national Spark Program project (No.: 2014GA740055). We like to express our appreciation for the valuable suggestions from the referee and the editor of this journal which significantly improved the quality of the presented paper.

\section{REFERENCES}

[1] Zhao Wenhai, Zou Chengcheng, Zhao Xiangmin. Preliminary exploration of project-based teaching in the field of computer application training. Heilongiiang science and technology information, 2012 (05).

[2] Song Jianjun. Problems and Countermeasures in the use of university teaching management system. Journal of Chongqing University of Science and Technology, 2010.16.

[3] Yu Liaohong, Liu Yingie, Li Jieting. Research on Application of teaching management system in teaching operation. Journal of Yichun University, 2008.04.

[4] Zhu Xiangcai, Wang Tailei, Hou Yingkun, Liu Mingxia,.5M5W practice teaching model research, [A]. University Computer Curriculum Report Forum Papers, 2007.06.

[5] Chen Buying. Simultaneous teaching of theory and professional skills in Higher Vocational Computer Science. Computer Knowledge and Technology, 2012 (03).

[6] Li Qi. Study on the combination of work and study in the teaching reform of computer major in Higher Vocational Education. Automation of Office Automation, 2010 (06).

[7] Zhou Yanyan. Analysis of key points and implementation path of computer teaching reform in Higher Vocational Education. China management information technology, 2016 (17). 